\title{
THE EMERGENCY PRICE CONTROL ACT OF 1942: CONSTITUTIONAL ISSUES
}

\author{
PaUl A. FreUnd*
}

Constitutional law, in the realm of national power, is compounded of equal parts of economics and procedure. On questions of basic power, Holmes' man of the future, the "man of statistics and the master of economics," has become the man of the present. On questions of delegation of power, the important inquiry is whether safeguards have been set up which tend to assure reasoned and not arbitrary action. This article, as I understand, is to be flanked by others concerned with the economic bases of the Act and with its procedural provisions. Thus my essay has been written for me. It only remains to show that this is so.

\section{Power of Congress}

The taking of measures to wage war successfully and to survive the war was a power as obviously conferred on the national government as it was dearly bought. In the exuberance of dicta the power has been painted with bold strokes. Thus in United States v. Macintosh, Mr. Justice Sutherland said:2

From its very nature, the war power, when necessity calls for its exercise, tolerates no qualifications or limitations, unless found in the Constitution or in applicable principles of international law. In the words of John Quincy Adams, - "This power is tremendous; it is strictly constitutional; but it breaks down every barrier so anxiously erected for the protection of liberty, property and of life." To the end that war may not result in defeat, freedom of speech may, by act of Congress, be curtailed or denied so that the morale of the people and the spirit of the army may not be broken by seditious utterances; freedom of the press curtailed to preserve our military plans and movements from the knowledge of the enemy; deserters and spies put to death without indictment or trial by jury; ships and supplies requisitioned; property of alien enemies, theretofore under the protection of the Constitution, seized without process and converted to the public use without compensation and without due process of law in the ordinary sense of that term; prices of food and other necessities of life fixed or regulated; railways taken over and operated by the government;

- A.B., 1928, Washington University; LL.B., I931, S.J.D., 1932, Harvard University. Member of the District of Columbia Bar. Professor of Law, Harvard University, since r940. Office of the Solicitor-General, U. S. Department of Justice, I935-1939; with Treasury Department and Reconstruction Finance Comporation, 1933-1935; law secretary to Mr. Justice Brandeis, I932-r933. Contributor to legal periodicals.

I The Path of the Law (1897) ro Harv. L. Rev. 457, 469, reprinted in Collected Legal Papers (1920) 167, 187. Compare MicReynolds, J., dissenting in Steward Machine Co. v. Davis, 30I U. S. 548, 599 (1937), speaking of interference with state powers: "... no cloud of words or ostentatious parade of irrelevant statistics should be permitted to obscure that fact."

${ }_{283}$ U. S. 605,622 (r93I). 
and other drastic powers, wholly inadmissible in time of peace, exercised to mect the emergencies of war.

More carefully, in Home Building \& Loan Association v. Blaisdell, Mr. Chief Justice Hughes said: ${ }^{3}$

The constitutional question presented in the light of an emergency is whether the power possessed embraces the particular exercise of it in response to particular conditions. 'Thus, the war power of the Federal Government is not created by the emergency of war, but it is a power given to meet that emergency. It is a power to wage war successfully, and thus it permits the harnessing of the entire energies of the people in a supreme coöperative effort to preserve the nation. But even the war power does not remove constitutional limitations safeguarding essential liberties.

The war powers are "not limited to victories in the field." They include the power, after the conflict has ended, to "remedy the evils which have arisen from its rise and progress." So said the Supreme Court after the War between the States, and the words were quoted by the Court after the World War in upholding the Prohibition Act passed after the Armistice."

To wage the present war successfully and to survive it requires, in the judgment of Congress and the President, that price inflation be limited. It needs no ghost from either the Revolution or the late World War to tell us of the danger of inflation in wartime. The danger is inherent in the special conditions of our wartime economy, marked as it is by shortages of materials and machines for civilian production, shortages of labor, extraordinary additions to income from government expenditures, and government borrowing which does not siphon off the income and bank deposits of the public. The power to control the inflationary rise of prices is a power to avoid the economic dislocation which would otherwise result. How that dislocation would fetter the conduct of the war and place in jeopardy our post-war stability is well understood. It would involve an enormous increase in the monetary cost of the war; stimulate hoarding of, and speculation in, needed materials; discourage productive undertakings; produce cleavages by the inequitable distribution of burdens; and foredoom a post-war collapse.

The power to prevent economic dislocation which threatens the practical success of basic constitutional functions is not a power peculiar to time of war. The regulation of the value of money by decreasing the gold content of the dollar would have produced enormous dislocation if gold-clause obligations were left to be enforced. To avoid the great and sudden increase that would have ensued in the dollar amount of such debts, they were converted into simple dollar obligations by Act of Congress,

290 U. S. 398,426 (I934).

Stewart v. Kahn, II Wall. 493, 507 (U. S. 1870), quoted in Hamilton v. Kentucky Distilleries \& Warehouse Co., 25I U. S. I46, I6I (Igrg). An extensive discussion of the war powers is contained in Hearings before House Committee on Banking and Currency on H. R. 5479, superseded by H. R. 599o, Price Control Bill, 75th Cong., rst Sess. (194I), Pt. I, p. 63 et seq.

"See Message of the President, July 30, 194r, 87 Cong. Rec. 6575, H. R. Rep. No. 1409, 77th Cong., Ist Sess. 
and in view of this context the legislative conversion was sustained. ${ }^{6}$ It is true that there the dislocation would have been caused by the enforcement of private agreements which were linked to the exercise of the devaluation power, and which were thus a clog of the most direct kind; but while this factor helped to support the striking down of antecedent contracts, it was not a limiting factor in the decision. The principle is more general, as is shown in the cases which uphold the regulation of intrastate prices where that regulation is necessary to the effective functioning of the interstate price system. The principle is well illustrated in United States v. Wrightwood Dairy Co., decided by the Supreme Court on February 2 of this year. ${ }^{7}$ The federal marketing orders for milk sold interstate provide minimum prices to be paid by handlers in accordance with the uses to which the milk is to be put, but producers are to be paid a uniform unit price, irrespective of the uses to which their milk is to be put; each handler pays into a settlement fund, or withdraws from it, the amount by which his payments to producers at the uniform price are less than, or exceed, as the case may be, the total value of the milk he has purchased, measured by the price established for its use classifications. Unregulated handlers doing an intrastate business in fluid milk, having the greatest value, may thus be in a position to pay to producers the uniform minimum price, or more, and enjoy a competitive advantage because they are not required to pay into the settlement fund the differential between the uniform price and the price for that classification. The inclusion of intrastate handlers under the orders was sustained as a concomitant to the regulation of interstate prices. The success of the latter regulation would otherwise have been jeopardized by the dislocation of the market.

At the present time price control is part of a complicated network of economic controls and hence should be considered, for constitutional purposes, as an adjunct to other measures taken under the war, monetary, and fiscal powers.

The system of priorities and allocations of important materials calls for accompanying price control. Such control serves to avert the injustices flowing from a distribution of scarce articles among consumers on the basis of soaring prices in the market. It serves also to avert "bootlegging and other forms of evasion."

Price control is an adjunct also of the power of the Government to requisition and

\footnotetext{
'Norman v. Baltimore and Ohio R. R., 294 U. S. 240 (I935). The nub of the case is indicated by the following colloquy, taken from a transcript of the oral argument:

"The Chief Justice (interposing): Now, I suppose your argument really comes to the point as to the consequences of maintaining the gold clause, with reference to its effect upon the exercise by Congress of the power which you say Congress has?

"Counsel: Yes, your Honor.

"The Chief Justice: That is the real point?

"Counsel: That is the real point. If Congress has the power, then that power cannot be whittled away-

"The Chief Justice: That is the point: Would the power be fettered if the gold clauses are maintained?

"Counsel: It certainly would be; it would be annihilated, as they say in the Legal Tender cases.

"The Chief Justice: Will you just show that in your argument?"

${ }^{7} 62$ Sup. Ct. 523 (x942).

${ }^{8}$ Baruch, Priorities-The Synchronizing Force (I94I) I9 Harv. Bus. Rev. 26r, reprinted in Barder, AMerican Industry IN THE WAR (194I) 465, 473; J. H. Martin, Present Status of Priorities (I94I) r9 Harv. Bus. Rev. 27I, 284 .
} 
to negotiate contracts of purchase. Without price control it is likely that a dual system of prices would prevail, one for the Government, arrived at by agreement or the fixing of fair market value, and another, more speculative, for private purchasers. The United States need not pay prices which reflect artificial enhancement. ${ }^{2}$ To allow more profitable private contracts would become intolerable. President Wilson in July, 1917, laid down the principle of a single régime of prices for government and public:10

We must make the prices to the public the same as the prices to the government. Prices mean the same thing everywhere now; they mean the efficiency or the inefficiency of the Nation, whether it is the government that pays them or not. They mean victory or defeat."

Professor Taussig explained the practical necessity which led the Price Fixing Committee to extend price ceilings over private dealings as well as government purchases: $:^{11}$

The process of fixing prices for the government but not for the public necessarily must have entailed sooner or later a rationing of the government orders, each producer to supply his proper quota to the government-a task obviously of great administrative difficulty. Hence, contemporaneously with the establishment of the Price-Fixing Committee itself, and for almost all transactions which came under the jurisdiction of that committee, the principle was followed of fixing a maximum price for all sales, whether to the government or to the public.

It is not suggested that maximum prices may be fixed in order to set the measure of just compensation in the event of requisitioning. They may be fixed in order to keep private prices in line with those paid by the Government, which may be arrived at by agreement or under the threat of economic sanctions only one of which is requisitioning. The question whether a maximum price order will be regarded ipso facto as the measure of compensation in case of taking is not essential to the present discussion but may appropriately be noticed. When the domestic market for gold was closed by Congressional and executive action in 1933-34, and access to the foreign markets was stringently restricted, the compensation which the Government was obliged to pay upon requisitioning of gold was held to be limited by the closure of the markets, so that prices abroad and prices paid by the Treasury for newly-mined gold were not to be taken into account. ${ }^{12}$ Somewhat similar is the holding that the United States as a contractor may avail itself of the defense of supervening im-

${ }^{9}$ See Highland v. Russell Car \& Snow Plow Co., 279 U. S. 253, 262 (1929).

${ }_{10}$ Address to Mine Operators and Manufacturers, 55 Cong. Rec. 4995, 4996, reprinted in 3 Publuc PAPERS of Woodrow Wrison (ed. Baker and Dodd, I925) 74, 78.

${ }^{11}$ Taussig, Price Fixing As Seen By a Price Fixer (1919) 33 Q. J. EcoN. 205, 215. Sec also Lcderer, War Economics, in WAR IN OUR TIME (ed. Speier and Kahler, 1939) 206, 215-216: "Two closely related measures which the capitalist state must pursue in its war economy are price control and rationing of consumption. The unavoidable deficiency of private production would in itself increase prices and thus either necessitate greater expenditures by the state or bring about a discrepancy between the prices charged to the public and the prices charged to the government, thus endangering the sufficient provision of the army. Price control avoids this situation and at the same time serves to control profits." See also Clankson, InDUSTRIal AMerica in the Worid WAR (1923) i65.

${ }^{12}$ Nortz v. U. S., 294 U. S. 317 (I935). See also Perry v. U. S., 294 U. S. 330,357 (1935), applying the same reasoning to a claim accruing even after the statutory price of gold had been increased. 
possibility caused by general wartime orders. ${ }^{13}$ In England, it is recounted, under regulations making a general price ceiling the maximum amount to be paid on requisitioning, advice of government counsel prevailed over the humorless nonlegal mind of the civil servant, so that instead of issuing a general price order and a requisitioning order at the same time, the former was studiously announced shortly in advance of the latter. ${ }^{14}$ As early as the Revolutionary War the relation of general price-fixing to commandeering of supplies was perceived.15 It seems likely that a legal corollary of a price order, though not its constitutional basis, will be to establish the value of a commodity which is requisitioned.

As an adjunct to priorities, allocations, government purchasing and requisitioning, price control is particularly appropriate in its application to selected commodities, including raw materials heavily needed for government orders and products made of those materials. Maximum price orders have, in addition, a more generalized function, to fortify the fiscal powers of Congress in a wartime economy. A rising plateau of prices means mounting dollar costs to the Treasury, and consequently mounting borrowing. It becomes increasingly necessary to borrow from the banks rather than from current consumer income, with the result that an inflationary credit base is created. ${ }^{16}$ The needs of the Treasury and the maintenance of credit controls come into sharp collision, as was indeed our experience in the late war. ${ }^{17}$ An excess-profits tax is not a specific for this danger. The tax will not absorb the full increase in prices, since some profits will not be reached and profits will not increase proportionately with prices where costs (another's prices) are also rising. Furthermore, it is pointed out, "The greater the rise in the price level, the more meaningless become comparisons of wartime profits with prewar, or calculation of invested capital, as a base for determining what are the 'excess' profits."18

It is possible to view price control even more broadly, as a regulation of the value of money. ${ }^{19}$ The monetary power admittedly carries with it the power to regulate

\footnotetext{
${ }^{13}$ Horowitz v. U. S., 267 U. S. 458 (1925). Compare also Samuels v. McCurdy, 267 U. S. I 88 (1925), holding that no compensation need be given for liquor taken by a state, where its commercial value had been destroyed by prohibitions on sale and transfer: "By valid laws, his property rights have been so far reduced that it would be difficult to measure their value. That which had the qualities of property has, by successive provisions of law in the interest of all, been losing its qualities as property." Cf. Note (1942) 55 Harv. L. Rev. 427, 531.

is See E. M. H. Lioyd, Experinents in State Control at the War Office and the Ministry of Foon (1924) 55. The Regulation was held, without special reference to the provision here mentioned, ultra vires under the governing legislation. Newcastle Breweries, Limited v. The King [1920] I K. $\mathrm{B}$. 854. But the Regulation appears to have been validated by the Indemnity Act, I920, IO \& II GEO. V, c. 4 8. Sir Cecil Carr has observed: "Classical writers on English constitutional law almost encourage the executive to break the law in a crisis, because the subsequent validation by statute exhibits such a triumph for the authority of the legislature." CARR, CONCERning English ADMinistrattve Law (I94I) 67.

${ }^{15}$ See Nevins, The American States During and After the Revolution (I927) 6i 8: "Congress ... asked the States to authorize the Continental Commissary officers to seize the goods of hoarders and speculators at the legalized prices."

${ }^{20} \mathrm{Cf}$. Pigou, The Political Econoniy of War (rev. ed. r94I) ir 8

${ }^{27}$ See Hardy, Wartiase Control of Prices (1940) $4 \mathrm{r}-42,210$.

${ }^{18}$ Id. at 17.

${ }^{10}$ See Ginsburg, Legal Aspects of Price Control in the Defense Program (1941) 27 A. B. A. J. 527, 530; cf. Taft, Price Fixing-A Necessary Evil, id. 534 .
} 
the price of one commodity-gold; the fixing of the gold content of the dollar is, of course, the fixing of a monetary price for gold, which may be made the exclusive market price. Under our gold standard, no other commodity stands in the same relationship to the dollar. It would hardly be contended that the power to regulate the value of the dollar could support the fixing of the value of the dollar in exchange for an isolated commodity, that is, the fixing of the price of that commodity. A more plausible argument can be made that the general level or movement of prices does represent the value of money and so can be validly controlled. The argument would receive support of a more technical sort if it were shown that the gold value of the dollar ought to be adjusted on the basis of the comparative domestic purchasing power of the dollar and that of other national currencies. ${ }^{20}$ But it seems unnecessary to pursue the extreme form of the argument. It is unnecessary, that is, to consider whether the power to regulate the value of money would include the power to fix minimum as well as maximum prices, and to do so at a time when the economic pressures of war are less dominant in the markets. The present Act, viewed as a monetary measure, serves to protect the currency against depreciation in markets which the exigencies of war have distorted. It is not without significance that the efforts at price control by the Continental Congress and the states during the Revolution were regarded, in part at least, as measures to save the currency. ${ }^{21}$ The monetary powers include the power "to secure a sound and uniform currency for this country."22 The more comprehensive the price orders in the number and importance of the commodities affected, and the more the prices are keyed to a fairly uniform base period, the more they bear this aspect of protection of the monetary system.

The precise ground on which the validity of a given price order may be rested will perhaps depend on the nature of the commodity. Whether it is controlled by priorities and allocations, the extent to which it is sold in interstate commerce, its importance in the cost of living, are among the factors which may determine the breadth of the ground taken to support constitutionality.

The judicial precedents on wartime price control reflect the general doctrine, current at the time of the late war and following it, that regulation of prices was a species of governmental power to be tested by special criteria under the due-process clause. The wonder, therefore, is not that the Supreme Court should have been cautious in its treatment of the question but rather that the price-fixing power exercised during the war managed to escape the general condemnation. Highland $\nu$. Russell Car \& Snow Plow Co. ${ }^{23}$ involved an order of the President under the Lever Act fixing a maximum price for coal sold by dealers. The seller was paid this price but had contracted for a higher price and sued the buyer for the difference. The buyer's defense, resting on the order, was upheld. The Court put emphasis on

${ }^{20} \mathrm{Cf}$. Casser, The World's Monetary Problems (x92r) 36-38.

${ }^{21}$ See W. G. Brown, A Continental Congressman: Oliver Ellsworth, 1777-1783 (1905), xo AM. Hrst. Rev. 75x, 76x; 15 J. Conr. Cong. 1289-I290 (Nov. 1779).

22 Veazie Bank v. Fenno, 8 Wall. 533, 549 (U. S. r869).

28279 U. S. 253 (1929). 
the fact that the coal was to be used in the manufacture of snow plows for railroads and could have been taken by eminent domain, at a figure no higher, for aught that appeared, than that set by the order. This was, to be sure, a roundabout way of upholding the order; but even in constitutional law we may by indirection find directions out. Perhaps the direction had been marked by Block $v$. Hirsh, ${ }^{24}$ sustaining the District of Columbia rent law as an emergency measure. ${ }^{25}$ The passage in the Macintosh case, already quoted, ${ }^{26}$ recognized a power to fix or regulate "prices of food and other necessities of life." In 1932, with these precedents at hand, Attorney General Mitchell ventured to advise the War Policies Commission that price control would be within the power of Congress if "reasonably necessary or proper for the efficient conduct of the war," and that "it can not now be said as a matter of law that the fixing of prices would necessarily be limited to the so-called necessaries."27 In the succeeding decade the removal of price-fixing and wage-fixing from a special category and their assimilation to other kinds of regulation have dispelled the due-process doubts. ${ }^{28}$

The question remains whether the price fixed must provide a fair return or reasonable profit to the sellers in an industry, or at all events to some of them. The problem is not one of just compensation, since the price orders do not constitute a taking by the United States. ${ }^{29}$ This is so even though the sale is to the United States at a price fixed by governmental order. ${ }^{30}$ The present Act expressly provides, in Section 4 (d), that it shall not be construed to require any person to sell any commodity. Apart, then, from just compensation, is any standard of return required? In Matthew Addy Co. v. United States, 31 a criminal prosecution under the Lever Act, the question was left undecided. The President fixed a margin of fifteen cents a ton for jobbers in bituminous coal; the defendant charged more than this margin in selling coal which he had purchased prior to the issuance of the order. The order was held inapplicable by its terms to the sale of such pre-acquired coal; otherwise, the Court said, "a grave constitutional question" would be presented in the case of a jobber whose selling expenses exceeded the margin fixed. The implication is that where both purchase and resale followed the order the question would not similarly arise. How this rationale can be applied to producers and manufacturers, as distinguished from distributors, is not clear.

A number of considerations suggest that a fair return or reasonable profit is not constitutionally required in fixing prices under the Act. In the first place, as has

${ }^{24} 256$ U. S. 135 (I92x).

${ }^{25}$ Cf. also Marcus Brown Holding Co., Inc. v. Feldman, 256 U. S. 170 (r921).

${ }^{20}$ Supra at 77.

${ }^{27}$ H. R. Doc. No. 27r, 72d Cong., Ist Sess. (1932) 34-38.

${ }^{28}$ Tagg Bros. \& Moorhead v. U. S., 280 U. S. 420 (r930); O'Gorman \& Young, Inc. v. Hartford Fire Ins. Co., 282 U. S. 25 X (r93I); Nebbia v. New York, 29 I U. S. 502 (I934); West Coast Hotel Co. v. Parrish, 300 U. S. 379 (1937); Townsend v. Yeomans, 30I U. S. 44 I (1937); U. S. v. Rock Royal CoOperative, Inc., 307 U. S. 533 (I939); Sunshine Anthracite Coal Co. v. Adkins, 310 U. S. 38I (r940);

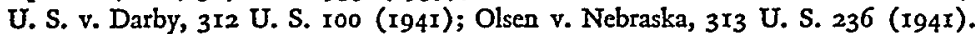

${ }^{20}$ Morrisdale Coal Co. v. U. S., 259 U. S. I88 (I922).

${ }^{30}$ American Smelting and Rfg. Co. v. U. S., 259 U. S. 75 (r922).

sx 264 U. S. 239 (1924). 
been stated above, the Act does not impose a duty to sell. In that important respect the public-utility cases are inapplicable; in so far as those cases rest on an analogy to a taking by eminent domain, the foundation is undercut in the present Act. And even in the public-utility field there is no constitutional guaranty of a profit if unreasonable rates are necessary to produce it. ${ }^{32}$ Moreover, the concept of fair return has not been applied to a business having relatively little physical property, but consisting largely of an organization of middlemen engaged in buying and selling on commission. ${ }^{33}$

Furthermore, with price control assimilated to other kinds of regulation, there seems little ground for judging price orders differently from wage orders or limitation of hours of labor or unemployment compensation. The latter regulations, it is true, affect the cost of doing business rather than the selling prices of products. Whether this difference has constitutional significance remains to be decided. In considering a milk dealer's attack on minimum purchase and resale price orders, the Court, in Hegeman Farms Corporation v. Baldwin, ${ }^{34}$ put to one side the cases concerned with maximum prices challenged by sellers. Having done so, the Court held unanimously that a showing by the plaintiff that it was operating at a loss under the orders did not relieve it of the duty of compliance. While the case is perhaps explainable on the ground that the plaintiff did not show whether its loss was due to the orders or to inefficiency which would lead to loss even if the orders were altered, still the differentiation of the problem of maximum prices is noteworthy. It is not, however, altogether satisfying. The state had fixed minimum prices to be paid to producers and minimum prices to be charged to consumers. The dealer complained that, since it had to pay the minimum price to producers, and had to sell at a price which competition had fixed at the minimum set by the state for sales by dealers, it was completely at the mercy of the orders. The Court answered that, while cost was fixed, the selling price was determined by competition, and would be higher if the efficient members of the industry found a higher price necessary. In the case of maximum rates, on the other hand, the efficient business may have to "break the law or bleed to death." The assumption does not seem adequate for generalized constitutional doctrine. The efficient utility may be able to reduce its costs sufficiently no less than the efficient dealer may be able to raise its prices sufficiently. The Constitution can hardly be said to make its protection depend on the end at which the profit margin is squeezed. The fixing of a floor on costs which results in loss of profit should be authority for the fixing of a ceiling on prices which has the same result.

In the Hegeman case no issue was presented of the validity of an order that would make all, or most, of the business done in the industry unprofitable. An Act of Congress authorizing price orders framed to suppress an industry would require justification addressed to the relevance of that design under the war and related

\footnotetext{
${ }^{32}$ Public Service Comm'n v. Great Northern Utilities Co., 289 U. S. 130, 135 (1933).

${ }^{33}$ Acker v. U. S., 298 U. S. 426 (I936).

${ }^{34} 293$ U. S. I63 (1934). See Note (1934) 34 CoL. L. Rev. 1336, 1339.
} 
powers. ${ }^{35}$ The present Act does not appear to authorize price orders for this purpose. The prices set must be in the judgment of the Administrator "generally fair and equitable" and such as will "effectuate the purposes of" the Act. Those purposes relate to profiteering, prevention of hardships, assurance of adequate production of commodities and services, prevention of post-war collapse, and stabilization of agricultural prices. So far as practicable, the Administrator must give due consideration to the prices prevailing between October I and October 15, I94I, or the nearest twoweek period in which the prices of the commodity are generally representative, with adjustments for general changes in costs and profits of sellers of the commodity during and subsequent to the year ended October I, I94T. Every order must be accompanied by a "statement of the considerations involved in the issuance of" such order. If those considerations are properly related to the declared purposes of the Act, it is difficult to conclude that an order would be constitutionally invalid because most or all of the enterprises in the industry would be unable to earn a profit on the commodity; the order would be as valid constitutionally as, for example, a minimumwage order having the same effect.

One further consideration should be mentioned: The problem of applying a test of fair return in an economy honeycombed with wartime controls. Is a competitive business constitutionally entitled to its pre-war rate of profit? Apart from businesses subject to the maximum-price orders, no such suggestion would be made. Is the test, then, whether a reasonable profit could be made in the absence of the price order? To separate out merely the price order seems artificial. The costs of the business may be kept down by the existence of a price order affecting raw materials used in the business. These orders may be adjusted to each other, and to accept one while attacking the other is hardly permissible. A certain supply of materials may also be assured under allocation orders, ${ }^{36}$ and these may presuppose a ceiling on the price of the finished product. A loss on a price-fixed product may be offset by government orders for other products. The problem goes beyond the technical rules of inseparability. It raises a doubt whether concepts of fair return are susceptible of practical application to a price order in an industry which is under a régime of interlacing government controls. To posit a peacetime economy, or a wartime economy with some controls removed and others retained, is to set up a standard which in its imaginative quality

\footnotetext{
${ }^{35}$ Compare Hamilton v. Kentucky Distilleries \& Warehouse Co., supra note 4. Choices between indusuries on economic grounds have frequently been made in federal and state legislation; e.g., Kentucky Whip \& Collar Co. v. Illinois Central R. R., 299 U. S. 334 (r937) (convict-made goods); Miller v. Schoene, 276 U. S. 272 (1928) (red cedar and apple trees), and cases there cited; and see the tax cases cited by Brandeis, J., dissenting, in Liggett Co. v. Lee, 288 U. S. 517, 570-571 (1933).

${ }^{30}$ During the late War, the automobile industry protested against the plan of the War Industries Board for sharply curtailed production of cars. When it was pointed out that the spokesman for the industry was assuming a supply of steel available when it would not be, he replied, "We are willing to take our chances. Get your one hundred per cent war programme. We will take our chances of the situation in steel breaking." The historian of the Board observes: "So great was the demand for steel for war purposes in the remaining months of the war that it was demonstrated that the Board's plan was essentially far more considerate of the industry than the take-the-chances plan advocated by Mr. Chalmers." Ciarkson, INDUSTRIAL AMERICA IN THE WORLD WAR (1923) 342-343.
} 
far outstrips the process of valuing a public utility by the calculation of reproduction cost new.

\section{Delegation of Power}

The discussion of Congressional power will have suggested that the factors entering into a determination of a "fair and equitable" price are to be dealt with on the administrative rather than the constitutional level. If this is so, the center of constitutional interest shifts to the issue of delegation of power to the Administrator.

The rule against delegation of power is an aspect of the larger guaranty of due process of law. So viewed, the standing of private parties to raise the issue becomes more readily explicable. The significant inquiry is whether the safeguards associated with the legislative process have a counterpart in the procedure which accompanies the delegation. ${ }^{37}$ Traditionally, however, the issue of delegation has been resolved by examining the legislative statement of policies and standards to decide whether they adequately circumscribe administrative discretion. It has been observed on high authority that the criteria applied are apt to be more indefinite than the legislative standards being examined. ${ }^{38}$ At all events, the process has about it an atmosphere of formalism if not of unreality. "Public interest, convenience, or necessity" has been approved as an adequate standard for the licensing of radio stations, ${ }^{30}$ though the first annual report of the Radio Commission contained a frank admission by one of its members of the large area of policy-making left for development: ${ }^{40}$

That, in just four words, is what Congress has told us to do. We are to determine who shall and who shall not broadcast and how such broadcasting shall be carried on, simply in accordance with our conception of public interest, convenience, or necessity.

It is a rather appalling responsibility....

... We can not evade this responsibility, for it is the thing which Congress has told us we must do, and it is the thing which the people of America rightly demand shall be done. The variety of broadcasting service has become infinite; how shall we measure the conflicting claims of grand opera and religious services, of market reports and direct advertising, of jazz orchestras and lectures on the diseases of hogs?

"Equalization of costs of production" was regarded as an adequate standard for the administration of the flexible tariff, ${ }^{41}$ though Chief Justice Taft, who delivered the Court's opinion, had declared when President that "the precise difference in cost of production sought for is not capable of precise ascertainment, and that all that even the most scientific person can do in his investigation is, after consideration of many facts which he learns, to exercise his best judgment in reaching a conclusion." "12

st "There is an obvious difference between legislative determination and the finding of an administrative official not supported by evidence. In theory, at least, the legislature acts upon adequate knowledge after full consideration and through members who represent the entire public." Southern Ry. v. Virginia, 290 U. S. I90, 197 (1933).

${ }^{88}$ Jackson, The Stzuggle for Judicial Supreanacy (I94I) 95.

39 Federal Radio Comm'n v. Nelson Bros. Co., 289 U. S. 266 (1933).

${ }^{\circ}$ ANN. Rep. Fed. Radio Comm'N, 1927, p. 6 (address of Commissioner Bellows).

${ }^{11}$ Hampton \& Co. v. U. S., 276 U. S. 394 (I928).

${ }^{42} \mathrm{~J}$. of Commerce, Aug. 20 and 29, rgro, quoted in Larkin, The Prestoent's Controu of the Tartpp (1936) 70. 
To the interests contesting these statutes, the delusive exactness of phrases was less important than assurance of a relatively reasoned and disinterested judgment. The procedure established, particularly in the case of the Radio Commission, and a comparison with the legislative process, particularly in the case of the tariff, might have been given greater due in reaching a conclusion favorable to the acts.

It is reassuring to find, in a decision of last Term, that the Court is taking a more comprehensive view of the issue of delegation, and is apparently regarding it as a problem of responsibility in government, to be resolved by an examination of all the safeguards which have been provided. In Opp Cotton Mills, Inc. v. Administrator of Wage and Hour Division, Mr. Justice Stone said $:^{\mathbf{4 3}}$

True, the appraisal of facts in the light of the declared policy and in conformity to prescribed legislative standards, and the inferences to be drawn by the administrative agency from the facts, so appraised, involve the exercise of judgment within the prescribed limits. But where, as in the present case, the standards set up for the guidance of the administrative agency, the procedure which it is directed to follow and the record of its action which is required by the statute to be kept or which is in fact preserved, are such that Congress, the courts and the public can ascertain whether the agency has conformed to the standards which Congress has prescribed, there is no failure of performance of the legislative function.

All this is not said by way of extenuation of the Price Control Act. By conventional tests the standards set forth in the Act are well within the limits of tolerance. The standards have already been described. Obviously they leave much to the judgment of the Administrator. On what commodities price orders should be placed; what is a fair and equitable price, for both the sellers and purchasers; what is a representative base period; what part of the industry shall be regarded as having representative costs; when shall a two-price system be established, to encourage production by high-cost producers; what weight shall be given to profits in the industry from the sale of other commodities, or to changes in unit costs caused by expansion or contraction of volume, or to additional investment in plant;-these are some of the questions that will have to be faced. They are not, however, different in kind from those which are commonly committed to administrative judgment. The objectives of the Act are coherent, and the weighing of the factors determining a fair price in the light of those objectives will be disclosed in the required statement of considerations accompanying a price order.

The flexible tariff, for all the seeming certainty of its "costs of production" formula, left a wider range of choice to the executive, not only in the arithmetic components of the rates but in the very objectives of the system. The fundamental choice was whether, of all the dutiable commodities, those should be selected for change whose rates were too low or too high. ${ }^{44}$ The law could serve for either a

${ }^{13} 312$ U. S. 126, 144 (194r).

"A "Addressing the House of Representatives on May 22, 1929, he [the late James M. Beck] said: "It is a beautiful law so long as you have a high-tariff President. You do not have to wait for Congress to Politics are precarious and now in a very fluid state. There might be an upheaval in Europe that will cause tells them to make a report upon this or that duty, and up goes the duty.

" 'But are you so certain that three years or seven years from now we will have a high-tariff President? propose anything. As the exigencies seem to justify, the President sends for the Tariff Commission and 
general upward or downward revision. Moreover, the factors entering into a comparison of costs permitted wide variations in the ultimate figure reached: the determination of principal competing country and the principal market of the United States; the choice of period of time for comparative study; the use of weightedaverage or bulk-line costs; the treatment of joint costs; the problem of comparing goods "like or similar"; the ascertainment of labor expenses; the question of including costs of distribution and transportation; and the meaning of "any other advantages or disadvantages in competition." But this is not all. While the President in altering rates was limited to a change of not more than $50 \%$, he could decide to change the classification of a commodity or to change the basis of valuation from foreign value to American selling price. It was thus possible to reduce a rate of 45 to $27.5 \%$ and at the same time bring about an increase in duty to $115 \%$ of the foreign value. ${ }^{45}$ This range of discretion is the more remarkable in the light of the fact that findings reciting the statutory formula are largely insulated from review. ${ }^{40}$

Statutory formulas may serve to conceal the problems of judgment which they create. Orderly administrative procedure, and a reference to the data and considerations employed, serve to expose and illuminate the problems. It is here, primarily, that we must look for safeguards comparable to those in the legislative process.

In time of war, particularly, when hardships will have to be borne as a matter of course, essential constitutional guaranties will be found in responsible procedures. This should be as true of price-fixing as of conscription of men. What is to be avoided is Lydford law. ${ }^{47}$ In procedural safeguards will be found the balance between governance and responsibility, between gubernaculum and jurisdictio, ${ }^{48}$ which has been at the core of the long struggle for constitutionalism.

a disruption of our economic system in this country, and the higher the wave is the more destructive its violence will be when the wave breaks. Let us imagine a low-tariff Democrat President, like my friend from Tennessee [Mr. Hull], one of the old guard for tariff for revenue only:' Reprinted in Beck, MAr ir

Please the Court (r930) 438." See Book Review (r937) 50 Harv. L. Rev. 7r8, 7rgn.

"See LaRkin, supra note 42, at 103-150, 87.

U. S. v. Bush \& Co., 310 U. S. 37 r (1940).

47 "I oft have heard of Lydford law, How in the morn they hang and draw,

And sit in judgment after."-William Browne.

${ }^{48}$ Mallwain, Consttrettonalisa, Ancient and Modern (I940) 549. 